Journal of Nutrition College, Volume 3, Nomor 2, Tahun 2014, Halaman 8-15

Online di : http://ejournal-s1.undip.ac.id/index.php/jnc

\title{
KANDUNGAN GIZI SOSIS SUBSTITUSI TEPUNG TEMPE DENGAN BAHAN PENGISI TEPUNG UBI JALAR KUNING (Ipomoea Batatas) DAN BAHAN PENSTABIL EKSTRAK RUMPUT LAUT (Eucheuma cottonii) UNTUK PMT IBU HAMIL
}

\author{
Dian Estiningtyas, Ninik Rustanti*) \\ Program Studi Ilmu Gizi Fakultas Kedokteran Universitas Diponegoro \\ Jl.Dr.Sutomo No.18, Semarang, Telp (024) 8453708, Email : gizifk@undip.ac.id
}

\begin{abstract}
ABSTRAK
Latar Belakang: Prevalensi anemia dan KEK pada ibu hamil masih tinggi. Masalah ini dapat diatasi dengan pemberian PMT. Sosis yang disubstitusi tepung tempe dengan bahan pengisi tepung ubi jalar kuning dan bahan penstabil ekstrak rumput laut dapat dimanfaatkan sebagai alternatif PMT Ibu hamil berbasis pangan lokal.

Tujuan: Menganalisis pengaruh substitusi tepung tempe terhadap tekstur dan kandungan gizi sosis dengan bahan pengisi ubi jalar kuning dan bahan penstabil ekstrak rumput laut.

Metode: Penelitian dilakukan 2 tahap, yaitu penelitian pendahuluan yang meliputi analisis bahan utama dan penentuan kadar substitusi tepung ubi jalar kuning sebagai bahan pengisi dan ekstrak rumput laut sebagai bahan penstabil dengan uji organoleptik dan penelitian utama yang menggunakan rancangan acak lengkap satu faktor yaitu substitusi tepung tempe dengan 3 taraf (20\%; 40\%; dan 60\%) dan 1 kontrol (0\% tepung tempe). Analisis tekstur dengan teksture analyzer, kadar protein dengan metode Kjeldahl, kadar lemak dengan metode Soxhlet, kadar karbohidrat dengan by difference dan kadar $\beta$-karoten dan zat besi dengan spektrofotometer. Selanjutnya, data dianalisis menggunakan One Way Anova.

Hasil: Semakin tinggi substitusi tepung tempe kadar protein, zat besi, dan $\beta$-karoten sosis semakin meningkat sedangkan kadar karbohidrat dan lemak semakin menurun. Sosis substitusi tepung tempe 60\% memiliki kadar protein, zat besi, dan $\beta$-karoten tertinggi, yaitu sebesar 23,24\%, 2,14 mg/100 g, dan 1,25 mg/100 g sedangkan kadar lemaknya terendah sebesar 24,20\%. Sosis substitusi tepung tempe 60\% sesuai Standar Nasional Indonesia (SNI 013820-1995), yaitu kadar protein minimal 13\%, lemak maksimal 25\%, dan karbohidrat maksimal $8 \%$.

Simpulan: Sosis substitusi tepung tempe 60\% dengan kecukupan angka kebutuhan gizi tambahan ibu hamil, protein sebesar $68 \%$, zat besi $12 \%$, dan $\beta$-karoten $35 \%$.

Kata kunci: tepung tempe; sosis; tekstur; kandungan gizi
\end{abstract}

\begin{abstract}
Background: Prevalence anemia and KEK (chronic lack of energy problem) on prenatal still high. This problem can be overcame one of them by supplementary feeding. Sausage with tempeh flour subtitution with filler yellow sweet potato flour and seaweed extract stabilizer can be used as suplementary feeding for pregnant woman with local food.

Objective: To analyze the effect of tempeh flour subtitution on the texture and nutritional content of sausage with yellow sweet potato floor and seaweed stabilizer.

Methods: This study was divided into two steps, which are preliminary study that analyzed main ingredients and determined the level of yellow sweet potato flour substitution as the content ingredient and seaweed as stabilizer with organoleptic test and main study that used randomized single factor-experimental study which was tempeh flour substitution with 3 levels (20\%; 40\%; and 60\%) and 1 control (0\% tempe flour). Texture was analyzed with Texture Analyzer, protein level with Kjedahl method, fat level with Soxhlet method, carbohydrate level with by difference and $\beta$-carotene \& iron level with Spektrofotometer. Data were analyzed with One Way Anova.

Result: The first study shown that higher tempeh flour substitution made enhancement of protein, iron and $\beta$ carotene levels on sausage, meanwhile carbohydrate and fat level were lower. Sausage with $60 \%$ tempeh flour substitution has highest protein, iron and $\beta$-carotene levels was 23,24\%, 2,14 mg/l00 g, dan $1,25 \mathrm{mg} / 100 \mathrm{~g}$ meanwhile fat level was the lowest 24,20\%. Then, 60\% tempeh flour substitution on sausage match with Standar Nasional Indonesia (SNI 01-3820-1995), was minimum 13\% protein, maximum $25 \%$ fat and $8 \%$ carbohydrate.

Conclusion: Best result shown by 60\% tempeh flour substitution on sausage which the nutritional content, and compared to nutrition content calculation for pregnant woman with protein was $68 \%$, iron $12 \%$, dan $\beta$-carotene $35 \%$.
\end{abstract}

Keywords: Pregnant woman supplementary feeding; texture; nutritional content; tempeh flour; filler; yellow sweet potato flour; bahan pengikat; and seaweed extract

${ }^{*}$ Penulis Penanggungjawab 


\section{PENDAHULUAN}

Kekurangan asupan zat gizi makro dan mikro pada ibu hamil dapat menyebabkan masalah gizi diantaranya anemia dan Kekurangan Energi Protein Kronis (KEK). Hal ini meningkatkan resiko melahirkan bayi dengan Berat Badan Lahir Rendah (BBLR) serta kematian ibu dan bayi. ${ }^{1}$ Berdasarkan data Riskesdas 2013, status gizi ibu hamil di Indonesia dengan anemia sebesar 37,1\% dan Kurang Energi Protein Kronis (KEK) pada ibu hamil $38,5 \% .^{2}$ Menurut penelitian terdahulu, ibu hamil yang menderita KEK atau anemia beresiko melahirkan bayi dengan BBLR sebesar 75,58\%. Data Angka Kematian Ibu (AKI) Nasional sebesar 307/100.000 kelahiran hidup. Penyebab kematian ibu diantaranya karena pendarahan yang 58\% dipicu oleh anemia selama masa kehamilan. Adapun angka kematian neonatal sebesar 987/100.000 kelahiran hidup. Penyebab kematian bayi $29 \%$ diantaranya karena ibu mengalami KEK pada masa kehamilan., ${ }^{2,3}$

Program pemerintah untuk mengatasi masalah gizi makro maupun mikro pada ibu hamil diantaranya pemberian suplemen, PMT ibu hamil, edukasi gizi, dan fortifikasi pangan. Pemberian suplemen dilakukan untuk mengatasi masalah gizi mikro pada ibu hamil. Namun menurut data Riskesdas tahun 2010 program tersebut masih kurang efektif. Hal ini ditunjukkan dengan tingkat konsumsi suplemen yang masih rendah yaitu $18 \%$. Khusus penanggulangan masalah gizi makro pada ibu hamil belum ada program yang berkesinambungan, selain pemberian makanan tambahan (PMT). ${ }^{2,4}$

Salah satu upaya yang dapat dilakukan untuk meningkatkan status gizi ibu hamil melalui PMT adalah dengan pengembangan makanan tambahan berbasis pangan lokal ${ }^{.5}$ Pemilihan jenis makanan tambahan didasarkan pada minat masyarakat. Salah satu jenis makanan yang banyak disukai dan dapat digunakan sebagai alternatif makanan tambahan adalah sosis. ${ }^{6}$

Sosis merupakan salah satu jenis produk praktis olahan daging yang dihaluskan, diberi bumbu, dan dimasukkan dalam selongsong. Konsumsi sosis di Indonesia semakin meningkat, yaitu pada tahun 1995 konsumsi per kapita hanya mencapai 2,9 g, meningkat menjadi 53,3 g per kapita per hari pada tahun $2000 .^{6}$ Pada umumnya sosis dibuat dari daging sapi, ayam, babi, kelinci, dan ikan. Daging mengandung kolesterol sebesar $42-80 \mathrm{mg} / 100 \mathrm{~g}$ yang bila dikonsumsi secara berlebihan akan meningkatkan resiko penyumbatan pembuluh darah (atherosklerosis) dan penyakit degeneratif. ${ }^{7,8}$ Oleh sebab itu dikembangkan sosis dari bahan nabati, salah satunya adalah tempe. ${ }^{9}$

Tempe merupakan bahan pangan lokal yang murah dan memiliki nilai gizi tinggi. ${ }^{10}$ Kandungan lemak tempe sebesar 2,89 g/100 g didominasi asam lemak tidak jenuh rantai panjang. Selain itu kadar protein tempe sebesar $18,3 \mathrm{~g} / 100 \mathrm{~g}$ dengan nilai cerna yang lebih tinggi, yaitu $83 \%$ dibandingkan dengan kedelai yang hanya $75 \% .^{11}$ Menurut penelitian terdahulu, penambahan tepung tempe $25 \%$ pada produk nugget daging kelinci mempunyai kadar protein sebesar $87,45 \%$. ${ }^{12}$ Tempe memiliki daya simpan kurang dari 2 hari sehingga untuk meningkatkan daya simpan perlu adanya pengolahan, salah satunya adalah penepungan. Substitusi tepung tempe, diharapkan selain meningkatkan nilai gizi sosis juga mampu menjadi alternatif makanan tambahan ibu hamil.

Penambahan tepung ubi jalar kuning sebagai bahan pengisi diperlukan untuk memperbaiki tekstur dan elastisitas sosis. Menurut penelitian terdahulu, penambahan ubi jalar kuning sebanyak $10 \%$ menjadikan produk beef nugget mempunyai mutu tekstur dan warna yang dinilai baik oleh panelis. ${ }^{13}$ Tepung ubi jalar kuning mengandung karbohidrat sebesar 83,19\%, $\beta$-karoten 250 - 500 $\mu \mathrm{g} / 100 \mathrm{~g}$, dan protein $4,42 \%$ dengan asam amino pembatas lisin. ${ }^{14}$ Adanya penambahan tepung ubi jalar kuning pada sosis, selain sebagai bahan pengisi diharapkan mampu meningkatkan $\beta$ karoten sosis.

Kualitas protein yang berasal dari golongan nabati masih tergolong rendah dibandingkan hewani, tetapi kombinasi sumber nabati yang bervariasi mampu memberikan efek komplementari asam amino essensial. Hal ini sesuai dengan perpaduan antara tepung tempe dan tepung ubi jalar kuning yang keduanya memiliki asam amino pembatas, yaitu tempe memiliki asam amino pembatas metionin yang dapat dilengkapi dengan ubi jalar kuning, sedangkan ubi jalar kuning memiliki asam amino pembatas berupa lisin yang dapat dilengkapi tempe. ${ }^{15}$

Penggunaan rumput laut sebagai bahan penstabil, diperlukan untuk menstabilkan emulsi dan membentuk gel tekstur sosis. ${ }^{16,17}$ Menurut penelitian terdahulu, penambahan rumput laut pada produk sosis ikan tenggiri sebanyak 2,5\% mampu meningkatkan stabilitas emulsi hingga $96 \% .{ }^{18}$ Rumput laut merupakan bahan pangan lokal yang mengandung zat gizi mikro penting untuk ibu hamil, yaitu zat besi. Penambahan rumput laut terbukti mampu meningkatkan kadar zat besi produk. Hal ini sesuai dengan penelitian terdahulu, 
penambahan rumput laut pada permen sebanyak $25 \%$ meningkatkan kadar zat besi hingga $6 x$ daripada kontrol. ${ }^{19}$ Salah satu jenis rumput laut yang banyak dimanfaatkan adalah Eucheuma cottonii. ${ }^{20}$ Selain itu, filtrat yang merupakan hasil samping dari pemanfaatan rumput laut sebagai bahan sosis dapat dimanfaatkan untuk edible film atau kemasan sosis yang bersifat elastis, dapat dimakan, dan aman untuk kesehatan. Kemasan ini selain sebagai upaya pemanfaatan filtrat ekstrak rumput laut diharapkan mampu mempertahankan mutu sosis. ${ }^{21}$

Berdasarkan latar belakang tersebut maka dilakukan penelitian mengenai pengaruh substitusi tepung tempe terhadap tekstur dan kandungan gizi sosis dengan bahan pengisi tepung ubi jalar kuning dan bahan penstabil ekstrak rumput laut sebagai PMT ibu hamil.

\section{METODA}

Penelitian yang dilakukan merupakan penelitian di bidang food production yang dilaksanakan mulai bulan Juni hingga November 2013 di Laboratorium pangan Universitas Muhammadiyah Semarang.

Penelitian dilakukan dalam 2 tahap, yaitu penelitian pendahuluan dan penelitian utama. Penelitian pendahuluan meliputi: analisis bahan utama dan penentuan perbandingan tepung ubi jalar kuning sebagai bahan pengisi dan ekstrak rumput laut sebagai penstabil dengan uji organoleptik menggunakan uji hedonik (tingkat kesukaan) pada panelis tidak terlatih sebanyak 30 orang ibu di Kelurahan Wonosari Semarang Selatan dengan 3 skala kesukaan, yaitu 1=Tidak Suka, 2=Netral, dan 3=Suka. Pada uji organoleptik ini terdapat 10 formulasi berupa 1 formulasi kontrol dan 9 formulasi subtitusi. Formulasi kontrol menggunakan $100 \%$ daging sebagai bahan utama sosis dan $10 \%$ tepung tapioka sebagai bahan pengisi sosis. Penelitian pendahuluan diperoleh formulasi yang disukai panelis adalah sosis dengan perbandingan tepung ubi jalar kuning dan ekstrak rumput laut sebesar 1:1 yang akan dianalisis pada penelitian utama seperti pada Lampiran 1.

Bahan baku tepung tempe dan tepung ubi jalar kuning dibuat dengan proses: pembersihan, pemotongan, blanching, pengeringan, dan pengayakan, sedangkan rumput laut diperoleh dari
Pasar Johar Semarang. Bahan baku tersebut dianalisis kandungan gizinya meliputi: kadar protein, lemak, karbohidrat, zat besi, dan $\beta$ karoten. Alat yang digunakan dalam pembuatan sosis antara lain: timbangan digital analitik, baskom, blender, mangkok, spatula, dan sendok. Proses pembuatan sosis diantaranya: tepung tempe, tepung ubi jalar kuning, ekstrak rumput laut, dan bumbu dicampur menjadi adonan, pengadukan, pengisian adonan ke dalam selongsong, perebusan selama 10 menit kemudian pengukusan 45 menit dan pendinginan sosis.

Penelitian utama menggunakan rancangan acak lengkap 1 faktor yaitu substitusi tepung tempe dengan 3 taraf (20\%; 40\%; dan 60\%) dan 1 kontrol (0\% tepung tempe) dengan 4 pengulangan sehingga diperoleh 16 satuan percobaan untuk dianalisis tekstur dan kandungan gizi.

Sosis dibungkus selongsong edible film yang terbuat dari hasil samping air saringan ekstrak rumput laut. Proses pembuatan edible film antara lain: perendaman rumput laut selama 24 jam, pemotongan, penghalusan dengan blender, perebusan 30 menit, pemisahan ekstrak dan filtrat, pemanasan, pengadukan, degassing, pencetakan, dan pengeringan dengan oven pada suhu $60^{\circ} \mathrm{C}-90$ ${ }^{\circ} \mathrm{C}$ selama 2 jam. ${ }^{20}$

Data yang dikumpulkan pada penelitian utama meliputi hasil analisis tekstur dengan Texture Analyzer, kadar protein dengan metode Kjeldahl, kadar lemak dengan metode Soxhlet, kadar karbohidrat dengan by difference dan kadar $\beta$ karoten dan zat besi dengan Spektrofotometer. ${ }^{22,23}$ Pengaruh variasi persentase substitusi tepung tempe terhadap tekstur dan kandungan gizi sosis diuji dengan One Way Anova (Analysis of Varience) dengan derajat kepercayaan $95 \%$ yang dilanjutkan dengan posthoc test Tukey untuk mengetahui beda nyata antar perlakuan.

\section{HASIL}

Hasil analisis kandungan gizi bahan baku sosis pada penelitian pendahuluan dapat dilihat pada Tabel 1. Hasil edible film yang dihasilkan berbentuk lembaran tipis, elastis, dan transparan (Lampiran 2). Edible film bersifat elastis karena pada saat proses pembuatannya ditambahkan gliserol sehingga berpengaruh pada kelenturan lapisan edible film yang dihasilkan. 
Tabel 1. Kandungan Gizi Bahan Utama Sosis

\begin{tabular}{|c|c|c|c|c|c|c|}
\hline \multirow{2}{*}{$\begin{array}{l}\text { Bahan } \\
\text { utama }\end{array}$} & \multicolumn{6}{|c|}{ Parameter } \\
\hline & $\begin{array}{l}\text { Air } \\
(\% \mathrm{~b} / \mathrm{b}\end{array}$ & $\begin{array}{l}\text { Protei } \\
\text { n } \\
(\%)\end{array}$ & $\begin{array}{l}\text { Lema } \\
\mathbf{k} \\
(\%)\end{array}$ & $\begin{array}{l}\text { Karbohidrat } \\
(\%)\end{array}$ & $\begin{array}{l}\text { Zat besi } \\
\text { (mg/100 } \\
\text { g) }\end{array}$ & $\begin{array}{l}\text { Vitamin A/ } \\
\beta \text {-karoten }\end{array}$ \\
\hline${ }_{4}^{*}$ Daging $^{2}$ & 67,2 & 18,8 & 14 & 0 & 2,8 & $30 \mathrm{SI}$ \\
\hline $\begin{array}{l}* * \text { Tepun } \\
\text { g tempe }\end{array}$ & 7,7 & 45,7 & 24,7 & 19,6 & 2,54 & - \\
\hline **Tepun & 6,77 & 4,42 & 0,91 & 83,19 & - & $481(\mu \mathrm{g} / 100$ \\
\hline $\begin{array}{l}\text { g ubi } \\
\text { jalar } \\
\text { kuning }\end{array}$ & & & & & & g) \\
\hline $\begin{array}{l}* * \text { Ekstra } \\
\text { k rumput } \\
\text { laut }\end{array}$ & & 9,47 & 1,36 & - & 141,26 & $\begin{array}{l}466,18 \quad(\mu \mathrm{g} \\
/ 100 \mathrm{~g})\end{array}$ \\
\hline $\begin{array}{l}* * \text { Tepun } \\
\text { g tapioka }\end{array}$ & 8,30 & 0,50 & 0,10 & 88,32 & - & - \\
\hline
\end{tabular}

Keterangan: *data sekunder, **data primer

\section{Tekstur}

Hasil analisis tekstur pada sosis substitusi tepung tempe, tepung ubi jalar kuning dan ekstrak rumput laut dapat dilihat pada Lampiran 3 dan secara singkat dapat dilihat pada Tabel 2.

Tabel 2. Hasil Analisis Tekstur Sosis Substitusi Tepung tempe

\begin{tabular}{cc}
\hline Substitusi Tepung Tempe & Parameter \\
\cline { 2 - 2 } & Tekstur $(\mathbf{m m})$ \\
\hline $\mathbf{0 \%}$ & $6,70 \pm 0,75$ \\
$\mathbf{2 0 \%}$ & $6,06 \pm 0,42$ \\
$\mathbf{4 0 \%}$ & $7,35 \pm 0,96$ \\
$\mathbf{6 0 \%}$ & $7,32 \pm 0,55$ \\
\hline & $\mathrm{p}=0,070^{*}$ \\
\hline
\end{tabular}

Keterangan : * Uji one way anova; tidak ada perbedaan bermakna antar kelompok. $(\mathrm{p}<0,05)$.

Tekstur sosis tertinggi adalah sosis substitusi tepung tempe $40 \%$ sebesar $7,35 \mathrm{~mm}$ dan tekstur terendah pada $20 \%$ yaitu $6,06 \mathrm{~mm}$ dibandingkan dengan kontrol sebesar 6,70 $\mathrm{mm}$. Hasil uji statistik menunjukkan bahwa substitusi tepung tempe tidak mempengaruhi tekstur sosis $(\mathrm{p}=0,070)$.

2. Kandungan Gizi

Hasil uji kandungan gizi sosis substitusi tepung tempe dapat dilihat pada Lampiran 3 dan secara singkat dapat dilihat pada Tabel 3 .

Tabel 3. Hasil Analisis Kandungan Gizi Sosis Substitusi Tepung Tempe

\begin{tabular}{|c|c|c|c|c|c|}
\hline \multirow{2}{*}{$\begin{array}{l}\text { Substitus } \\
\text { i Tepung } \\
\text { Tempe }\end{array}$} & \multicolumn{5}{|c|}{ Parameter } \\
\hline & $\begin{array}{l}\text { Protein } \\
(\%)\end{array}$ & $\begin{array}{l}\text { Lemak } \\
(\%)\end{array}$ & $\begin{array}{l}\text { Karbohidrat } \\
(\%)\end{array}$ & $\begin{array}{l}\text { Zat besi } \\
(\mathbf{m g} / \\
\mathbf{1 0 0 g})\end{array}$ & $\begin{array}{l}\beta \text {-karoten } \\
(\mathbf{m g} / \mathbf{1 0 0} \mathbf{g})\end{array}$ \\
\hline $0 \%$ & $9,21 \pm 1,21^{\mathrm{d}}$ & $28,19 \pm 2,23$ & $18,44 \pm 2,80^{\mathrm{a}}$ & $2,08 \pm 0,12^{\mathrm{a}}$ & $1,03 \pm 0,12^{b}$ \\
\hline $20 \%$ & $14,34 \pm 0,76$ & $26,21 \pm 1,01$ & $15,00 \pm 0,75^{b}$ & $0,33 \pm 0,11^{\mathrm{c}}$ & $0,32 \pm 0,03^{\mathrm{d}}$ \\
\hline $40 \%$ & $\mathrm{~b}_{\mathrm{b}}^{17,98 \pm 1,16}$ & $25,56 \pm 1,16$ & $10,96 \pm 2,15^{b}$ & $0,89 \pm 0,23^{b}$ & $0,73 \pm 0,07^{\mathrm{c}}$ \\
\hline
\end{tabular}




\begin{tabular}{|c|c|c|c|c|c|}
\hline $60 \%$ & $\underset{a}{23,24 \pm 1,20}$ & $24,20 \pm 2,85$ & $6,75 \pm 0,03^{b}$ & $2,14 \pm 0,16^{\mathrm{a}}$ & $1,25 \pm 0,12^{\mathrm{a}}$ \\
\hline & $\begin{array}{l}\mathrm{p}=0,000 \\
* *\end{array}$ & $\begin{array}{l}\mathrm{p}=0,082 \\
*\end{array}$ & $\begin{array}{l}\mathrm{p}=0,003 \\
* * *\end{array}$ & $\begin{array}{l}\mathrm{p}=0,005 \\
* * *\end{array}$ & $\begin{array}{l}\mathrm{p}=0,000 \\
* * *\end{array}$ \\
\hline
\end{tabular}

Keterangan : * Uji Oneway Anova; ** Uji one way anova; dilanjutkan dengan Tukey $(\mathrm{p}<0,05)$. *** Uji Kruskal-Wallis; dilanjutkan dengan Mann-Whitney ( $\mathrm{p}<0,05)$. Huruf superscript yang berbeda $(\mathrm{a}, \mathrm{b}, \mathrm{c})$ menunjukkan beda nyata $(\mathrm{p}<0,05)$

Kadar protein tertinggi pada sosis substitusi tempe $60 \%$ sebesar $23,24 \%$. Semakin tinggi substitusi tepung tempe, maka kadar protein sosis semakin meningkat secara signifikan $(\mathrm{p}=0,000)$. Hasil uji kandungan lemak menunjukkan semua sosis substitusi tepung tempe mempunyai kadar lemak lebih rendah dibandingkan kontrol sebesar 28,19\%. Semakin tinggi substitusi tepung tempe, maka kadar lemak sosis semakin menurun tetapi tidak signifikan secara statistik $(\mathrm{p}=0,082)$.

Hasil uji kandungan karbohidrat menunjukkan semua sosis substitusi tepung tempe mempunyai kadar karbohidrat lebih rendah dibandingkan kontrol sebesar $18,44 \%$. Semakin tinggi substitusi tepung tempe, maka kadar karbohidrat semakin menurun secara signifikan $(\mathrm{p}=0,003)$.

Kadar zat besi tertinggi pada sosis substitusi tepung tempe $60 \%$ sebesar $2,14 \mathrm{mg} / 100 \mathrm{~g}$ dibandingkan dengan kontrol sebesar 2,08 mg/100 $\mathrm{g}$ tetapi pada formulasi tepung tempe $20 \%$ dan $40 \%$ lebih rendah daripada kontrol, yaitu $0,33 \mathrm{mg}$ dan $0,89 \mathrm{mg} / 100 \mathrm{~g}$. Semakin tinggi substitusi tepung tempe, maka kadar zat besi semakin meningkat secara signifikan $(\mathrm{p}=0,005)$.

Kadar $\beta$-karoten tertinggi pada kelompok substitusi $60 \%$ sebesar $1,25 \mathrm{mg} / 100 \mathrm{~g}$. Semakin tinggi substitusi tepung tempe, maka kadar $\beta$ karoten sosis semakin meningkat secara signifikan $(\mathrm{p}=0,000)$.

\section{PEMBAHASAN}

\section{Tekstur}

Hasil analisis tekstur sosis substitusi tepung tempe dengan Texture Analyzer menggambarkan daya tahan produk oleh adanya gaya tekan atau kemampuan kembalinya bahan pangan yang ditekan ke kondisi awal setelah beban tekanan dihilangkan. ${ }^{25}$ Menurut hasil uji tekstur tingkat kekenyalan tekstur tertinggi adalah sosis substitusi tepung tempe $40 \%$ sebesar $7,35 \mathrm{~mm}$ dan tekstur terendah pada $20 \%$ yaitu $6,06 \mathrm{~mm}$ dibandingkan dengan kontrol sebesar $6,70 \mathrm{~mm}$. Substitusi tepung tempe tidak mempengaruhi tekstur sosis secara signifikan $(\mathrm{p}=0,070)$. Hal ini disebabkan, tekstur pada sosis dipengaruhi oleh kadar air, karena air diikat oleh tepung tempe dalam sosis sehingga semakin tinggi substitusi tepung tempe, menyebabkan tekstur sosis menjadi lebih lunak. ${ }^{25,26}$

\section{Kandungan Gizi}

Kadar protein tertinggi pada sosis substitusi tempe $60 \%$ sebesar 23,24\%. Semakin tinggi substitusi tepung tempe, maka kadar protein sosis semakin meningkat secara signifikan $(\mathrm{p}=0,000)$. Hal ini disebabkan kadar protein pada sosis dipengaruhi oleh substitusi tepung tempe dengan kandungan protein sebesar $45,7 \%$ yang lebih tinggi daripada kadar protein sosis kontrol berupa daging dengan kandungan protein sebesar $18,8 \%$. Kadar protein sosis substitusi tepung tempe $20 \%$, $40 \%$, dan $60 \%$ sudah sesuai Standar Nasional Indonesia (SNI 01-38201995) pada sosis, yaitu protein minimal $13 \%$.

Mutu protein pada produk pangan bukan hanya ditentukan dari kadar protein tetapi juga kandungan asam amino esensial dan mutu cernanya. Selain itu dengan adanya substitusi tepung tempe dan tepung ubi jalar kuning akan memberikan efek komplementari asam amino essensial pembatas, yaitu metionin pada kedelai dan lisin pada ubi jalar kuning. ${ }^{27}$ Hal ini terbukti, bahwa penambahan tepung tempe mampu meningkatkan kandungan asam amino essensial lisin dan metionin sosis berdasarkan perhitungan kandungan gizi menggunakan software National Nutrient Database for Standar Reference 2012 yang dapat dilihat pada Lampiran 4.

Hasil uji kandungan lemak menunjukkan semua sosis substitusi tepung tempe mempunyai kadar lemak lebih rendah dibandingkan kontrol sebesar 28,19\%. Kadar lemak pada sosis terendah terdapat pada sosis substitusi tepung tempe $60 \%$ sebesar $24,20 \%$. Semakin tinggi substitusi tepung tempe, maka kadar lemak sosis semakin menurun tetapi tidak signifikan secara statistik $(\mathrm{p}=0,082)$. Hal 
ini dipengaruhi kandungan lemak dan asam lemak masing-masing bahan utama. Tepung tempe mengandung lemak dengan berat kering sebesar 26,76\% sedangkan daging mengandung lemak dengan berat kering sebesar $42,68 \%$ seperti yang dapat dilihat di lampiran 5. Asam lemak tepung tempe mengandung asam lemak tidak jenuh rantai panjang berupa asam linoleat, asam linolenat, dan asam oleat yang lebih cepat teroksidasi daripada asam lemak jenuh pada daging (asam strearat dan asam palmitat). Proses pemanasan pada pembuatan sosis menyebabkan asam linoleat berubah menjadi hidroperoksida sehingga kadar lemak sosis menurun. ${ }^{11,28}$ Kadar lemak sosis substitusi tepung tempe 40\% dan 60\% sudah sesuai dengan Standar Nasional Indonesia (SNI 01-3820-1995) pada sosis, yaitu lemak minimal 13\%. Selain itu, pada sosis substitusi tepung tempe 60\% terkandung kolesterol sebesar $10 \mathrm{mg} / 100 \mathrm{~g}$ sedangkan pada sosis kontrol sebesar 27 $\mathrm{mg} / 100 \mathrm{~g}$ yang melebihi batasan anjuran kolesterol makanan selingan yang ditetapkan yaitu $25 \mathrm{mg} / 100 \mathrm{~g}$ seperti pada lampiran 6 .

Kadar karbohidrat tertinggi pada sosis substitusi tempe $20 \%$ sebesar $15,00 \%$ dibandingkan dengan kontrol sebesar 18,44\%. Semakin tinggi tepung tempe yang ditambahkan, maka kadar karbohidrat semakin menurun secara signifikan $(\mathrm{p}=0,003)$. Hal ini disebabkan pada sosis kontrol ditambahkan $10 \%$ tepung tapioka yang mengandung karbohidrat sebesar 88,32\% sebagai bahan pengikat dan penstabil sedangkan pada perlakuan ditambahkan $20 \%$ $60 \%$ tepung tempe dengan kadar karbohidrat sebesar 19,6\%. ${ }^{29}$ Menurunnya kadar karbohidrat sosis dikarenakan analisis karbohidrat menggunakan by difference yang perhitungannya dipengaruhi oleh kadar protein dan lemak sosis. Kadar karbohidrat sosis substitusi tepung tempe $60 \%$ sudah sesuai dengan nilai gizi Standar Nasional Indonesia (SNI 01-3820-1995) pada sosis, yaitu karbohidrat minimal 13\%.

Kadar zat besi tertinggi pada sosis substitusi tepung tempe $60 \%$ sebesar 2,14 $\mathrm{mg} / 100 \mathrm{~g}$ dibandingkan dengan kontrol sebesar $2,08 \mathrm{mg} / 100 \mathrm{~g}$ tetapi pada formulasi tepung tempe $20 \%$ dan $40 \%$ lebih rendah daripada kontrol, yaitu $0,33 \mathrm{mg}$ dan 0,89 $\mathrm{mg} / 100 \mathrm{~g}$. Semakin tinggi tepung tempe yang ditambahkan, maka kadar zat besi semakin meningkat secara signifikan $(\mathrm{p}=0,005)$. Hal ini disebabkan karena tepung tempe mengandung zat besi sebesar $2,54 \mathrm{mg} / 100 \mathrm{~g}$, sehingga semakin tinggi substitusi tepung tempe semakin meningkat kadar zat besi sosis. Zat besi yang diperlukan selama kehamilan meningkat sekitar $9 \mathrm{mg}$ sehingga sosis substitusi ini mencukupi $12 \%$ dari kebutuhan tambahan ibu hamil. Zat besi penting bagi ibu hamil, karena zat besi diperlukan untuk pembentukan sel darah merah dan membantu dalam proses peredaran oksigen dalam darah pada ibu dan janin. Kekurangan asupan zat besi pada masa kehamilan meningkatkan resiko melahirkan bayi dengan Berat Badan Lahir Rendah serta kematian bagi ibu dan bayi. ${ }^{1,3}$

Kadar $\beta$-karoten tertinggi pada kelompok perlakuan substitusi $60 \%$ sebesar $1,25 \mathrm{mg} / 100$ g. Semakin tinggi substitusi tepung tempe, maka kadar $\beta$-karoten sosis semakin meningkat secara signifikan $(\mathrm{p}=0,000)$. Hal ini disebabkan, sosis dengan bahan pengisi ubi jalar kuning mengandung $\beta$-karoten 250$500 \mu \mathrm{g} / 100 \mathrm{~g}$, lalu disubstitusi dengan tepung tempe yang berbahan dasar kedelai dengan kadar $\beta$-karoten 44,5 $\mu \mathrm{g}$. Fermentasi tempe menjadikan $\beta$-karoten meningkat hingga $30 \%$ karena pengaruh metabolisme mikroorganisme saat proses fermentasi. ${ }^{30}$

Kontribusi PMT ibu hamil ditentukan berdasarkan hasil analisis kadar energi, protein, lemak, zat besi, dan $\beta$-karoten dibandingkan dengan nilai gizi Standar Nasional Indonesia (SNI 01-3820-1995) pada sosis dan AKG (Angka Kecukupan Gizi) ibu hamil. Kandungan protein, zat besi dan $\beta$ karoten sosis substitusi tepung tempe $60 \%$ per $100 \mathrm{~g}$ paling tinggi dibanding dengan sosis substitusi tepung tempe $20 \%$ dan $40 \%$. Pada $100 \mathrm{~g}$ sosis mampu mencukupi kebutuhan protein, zat besi dan $\beta$-karoten ibu hamil sebesar $68 \%, 12 \%$, dan $35 \%$. Selain itu, pada sosis substitusi tepung tempe $60 \%$ terkandung kolesterol sebesar $10 \mathrm{mg} / 100 \mathrm{~g}$ yang masih dalam batasan anjuran kolesterol makanan selingan yang ditetapkan, yaitu $25 \mathrm{mg} / 100 \mathrm{~g}$ sedangkan pada sosis kontrol sebesar 27 $\mathrm{mg} / 100 \mathrm{~g}$. Hal ini diharapkan sosis substitusi tepung tempe $60 \%$ mampu memberikan kandungan gizi yang paling baik sehingga dapat mencukupi kebutuhan gizi ibu hamil.

SIMPULAN DAN SARAN 


\section{A. Simpulan}

1. Semakin tinggi substitusi tepung tempe kadar protein, zat besi, dan $\beta$-karoten sosis semakin meningkat sedangkan kadar karbohidrat dan lemak semakin menurun.

2. Hasil sosis substitusi tepung tempe $60 \%$ direkomendasikan dengan kecukupan angka kebutuhan gizi tambahan ibu hamil, protein $68 \%$, zat besi $12 \%$, dan $\beta$-karoten $35 \%$ dan sesuai dengan Standar Nasional Indonesia (SNI 01-3820-1995) dengan kadar protein minimal 13\%, lemak maksimal 25\%, dan karbohidrat maksimal $8 \%$.

\section{B. Saran}

1. Perlu penelitian lebih lanjut untuk menghasilkan produk PMT dengan zat besi dan $\beta$-karoten yang lebih tinggi untuk mencukupi kebutuhan zat besi dan $\beta$ karoten pada ibu hamil.

2. Perlu penelitian lebih lanjut mengenai pemanfaatan filtrat rumput laut untuk edible film yang sesuai dengan standar pembungkus produk makanan.

\section{UCAPAN TERIMA KASIH}

Puji syukur penulis panjatkan kepada Allah SWT yang telah memberikan karunia dan kemudahan dalam menyelesaikan karya tulis ini. Terima kasih ditujukan pada PT Indofood Sukses Makmur Tbk. yang telah memberikan bantuan dana penelitian dalam program Indofood Riset Nugraha Periode 2013-2014, Alm. Bapak Sri Sujoto selaku Ayah Saya, dan Ibu Ninik Rustanti, S.TP, M.Si selaku pembimbing serta pihak-pihak yang telah memberikan dukungan dan bantuan sehingga penelitian ini dapat diselesaikan dengan baik.

\section{DAFTAR PUSTAKA}

1. Black RE. Micronutrients in Pregnancy. Br J Nutr 85 Suppl 2: S193. 2001

2. Riskesdas 2013. Badan Penelitian dan Pengembangan Kesehatan Kementrian Kesehatan RI. 2013

3. Departemen Kesehatan. Kerangka Kebijakan Gerakan Sadar Gizi dalam Rangka Seribu Hari Pertama Kehidupan. Jakarta : 2012

4. Kementrian kesehatan RI. Pedoman Gizi Ibu Hamil dan Pengembangan Makanan Tambahan Ibu Hamil Berbasis Pangan Lokal. 2010

5. Depkes. Panduan PMT Balita dan Ibu Hamil. 2012

6. Agus Hadi Prayitno. Karakteristik Sosis Dengan Fortifikasi B-Caroten Dari Labu Kuning. Buletin peternakan vol 33(2):111-118, juni 2009. Fakultas
Peternakan. Yogyakarta : Universitas Gajah Mada. 2009

7. Center of Nutrition Policy and Promotion. Dietary Saturated Fat And Cardiovascular Health : A Review Of The Evidence. US Department of Agriculture. july 2011

8. Marcela. Human Health Effects of Fatty Acids in Beef. Extension Service West Virginia University. August 2003

9. Tekno Pangan dan Agro Industri, Volume 1, Nomor 12. Sosis Tempe. Jurusan Teknologi Pangan Dan Gizi. Bogor : Institut Pertanian Bogor. 2006

10. Astuti, M., Meliala, Andreanyta., Fabien, Dalais., Wahlq, Mark. Tempe, a Nutrisious and Healthy Food From Indonesia. Asia Pasific J Clin Nutr 9(4): 322-325. 2003

11. Diah. Kandungan Asam Lemak, Zink, dan Copper pada Tempe, Bagaimana Potensinya untuk Mencegah Penyakit Degeneratif. Departemen Gizi Kesehatan Masyarakat Fakultas Kesehatan Masyarakat. Jakarta : Universitas Indonesia. 2010

12. Dheviana Widhia. Kualitas Kimia dan Organoleptik Nugget Daging Kelinci dengan Penambahan Tepung Tempe. Fakultas Pertanian Universitas Sebelas Maret Surakarta. 2010

13. Kusrahayu. Pengaruh Berbagai Filler (Bahan Pengisi) Terhadap Sifat Organoleptik Beef Nugget. Fakultas peternakan dan pertanian Universitas Diponegoro. 2013

14. Indrie Ambarsari, Abdul Choliq. Rekomendasi dalam Penetapan Standar Mutu Tepung Ubi Jalar. Jurnal Standardisasi 11(3): 212-219. 2009

15. Winarno. Kimia Pangan dan Gizi. Jakarta : PT Gramedia Pustaka Utama; 2002. P. 50-115

16. Atmadja WS, Kadi A, Sulistijo, Rachmaniar. Pengenalan Jenis-Jenis Rumput Laut Indonesia. Jakarta: PUSLITBANG Oseanologi. LIPI. 1996

17. Dian Y. Optimasi Proses Ekstraksi pada Pembuatan Karaginan dari Rumput Laut Eucheuma Cottonii untuk Mencapai Foodgrade. Jurusan Teknik Kimia. Semarang : Universitas Diponegoro. 2011

18. Egi L, Widodo F, Putut H. Aplikasi Karagenan Sebagai Emulsifier di dalam Pembuatan Sosis Ikan Tenggiri Pada Penyimpanan Suhu Ruang. Jurnal perikanan volume 1, nomor 2, halaman 1 . Semarang : Universitas Diponegoro. 2012

19. Anita Y. Kadar Zat Besi, Serat, Gula Total, dan Daya Terima Permen Jelly dengan Penambahan Rumput Laut Gracilaria $S p$ dan Sargassum Sp. Program Studi Ilmu Gizi. Universitas Diponegoro. 2011

20. Diana S. Pembuatan Mie Remas Instan dari Ekstrak Rumput Laut (Eucheuma Cottonii). Laporan akhir PKM. Dibiayai oleh Direktorat Jenderal Pendidikan Tinggi. 2009

21. Donhowe E, Fennema O. Edible Films and Coatings : Characteristic, Formation, Definition 
and Testing Methods. Edibel Coatings and Films to Improve Food Quality Technomic Publishing Company, Inc. Lancaster : Pennsylvania. 1994

22. Abdul R. Analisis Makanan. Gadjah Mada University press. Jogjakarta. 2007

23. AOAC. Method of analysis. Association of official analytical chemistry, Washington, DC. 1984

24. Amrih. Tinjauan Gizi, Finansial dan Mikrostruktur Otot dari Sapi Glonggongan. Seminar Nasional Teknologi Peternakan. Balai Pengkajian Teknologi Pertanian Jawa Tengah. 2009

25. Elok Z. Studi Kualitas Fisik-Kimiawi dan Organoleptik Sosis Ikan Lele Dumbo Akibat Pengaruh Perebusan, Pengukusan, dan Kombinasinya dengan Pengasapan. Jurusan Teknologi Hasil Pertanian Vol 4. No 3: 193-202, FTP Unibraw. Malang. 2012

26. Hotnida S. Pemanfaatan Tepung Kedele dan Tepung Tempe sebagai Bahan Substitusi Daging dalam Pembuatan Bahan Pangan. Perpustakaan Universitas Indonesia. Laporan penelitian Dikti. 2010

27. Whitney E. Understanding Nutrition. 11th ed.USA:Thomson Wadsorth; 2007.p.181-198

28. Farihah W. Perbandingan Asam Lemak Hewani dan Nabati. Lokakarya Fungsional Non Peneliti. Bogor. 2001

29. Ria A. Subtitusi Tepung Tapioka dalam Pembuatan Takoyaki. Jurusan Ilmu dan Teknologi Pangan Fakultas Pertanian. Surakarta: Universitas Sebelas Maret. 2013

30. Niken L. Produksi Betakaroten pada Limbah Padat Tempe: Kajian Jenis Kapang. Jurnal Teknologi Pertanian Vol 4(2): 108-122. Fakultas Teknologi Pertanian. Malang: Universitas Brawijaya. 2008 